\title{
The Effect of Enterprise Risk Management on Ameliorating Competitive Advantage: A Cross-Sectional Study of Software Houses in Pakistan
}

\author{
Sameeta Javaid ${ }^{1}$ and Faheem Aslam ${ }^{1,2 *}$ \\ ${ }^{1}$ Department of Management Sciences, Comsats University, Islamabad 45550, Pakistan \\ ${ }^{2}$ Business School, Hanyang University, Seoul 04763, Korea
}

\begin{abstract}
In the current dynamic environment, organizations need a more anticipatory and effective risk management system. Implementing the holistic Enterprise Risk Management (ERM) process will perceive, analyze, and assess risks as they must be regarded from the entire enterprise's perspective. The research aims to empirically analyze the effect of ERM practices on the Competitive Advantage (CA) and examine the moderating role of Organizational Culture (OC) in the Software industry of Pakistan. The primary data were obtained from 250 respondents through the questionnaire method. The validity and reliability were analyzed by using Structural Equation Modeling Analysis, PLS Algorithm, and Bootstrapping. The results show that the implementation of ERM has a significant effect on firms' competitive advantage. The analysis supports the hypothesis and identifies the positive moderating effect of organizational culture in carrying out ERM programs, which can enhance organizational competitiveness. This study is useful for managers to help them in the planning and decision-making phase so that they can act responsibly in a rapidly changing environment and consider organizational culture as one of the key factors of the ERM program that helps accomplish organizational competitiveness.
\end{abstract}

Keywords: Competitive advantage, enterprise risk management, organizational culture, software industry

ARTICLE INFO

Article history:

Received: 11 March 2021

Accepted: 08 September 2021

Published: 08 December 2021

DOI: https://doi.org/10.47836/pjssh.29.4.24

$\overline{\text { E-mail addresses: }}$

Sameeta javaid@yahoo.com (Sameeta Javaid)

Faheem.aslam@comsats.edu.pk (Faheem Aslam)

* Corresponding author

\section{INTRODUCTION}

Currently, organizations are getting affected by several risks factors, for example, globalization, change in the environment, technological advancements, complex financial models, and corporate governance changes (Gatzert \& Martin, 2015; Tekathen 
\& Dechow, 2013). In a modern business environment, achieving organizational competitiveness becomes one of the key challenges. Companies are required to work on new knowledge and methods and to pursue the practical wisdom that enables them to develop a competitive edge (Nonaka et al., 2014). Enhancement of competitive advantage strictly relies on the organizational management system (Simons, 1990). Managers are continuously working to create and expand their knowledge on the competitive business advantage based on the capability to establish a system for generating and protecting the firm's resources (Grant, 1996). Organizations having effective risk management systems can easily cope up with uncertain and complex environmental changes.

Traditional risk management deals with assigning risk management to each department, primarily responsible for the risks within its own business. Hence in the past, numerous organizational failures occurred due to a traditional risk management approach that damaged the company's viability (Ching et al., 2020). Enterprise risk management (ERM) is recognized as a newfangled way for managing no. of risks like strategic, operational, and financial occurrences in organizations. It also effectively deals with an organizational control system in an organized and systematic manner (Hoyt \& Liebenberg, 2011; Olson \& Wu, 2015). It is an approach used for managing risk and is also a tool for controlling the internal system of organizations that enables them to improve resource allocation and proper utilization of those assets (Berry-Stölzle \& Xu, 2018; Jabbour \& Abdel-Kader, 2015). Despite the increasing spotlight on ERM in Asia, Empirical evidence on ERM is missing as the modern way of minimizing negative factors as the majority of studies concentrate on the extent of ERM adoption in developed countries. This system received very little attention in how it helps in increasing competitive advantage (Chen et al., 2020). Many organizational factors are directly influencing ERM function; like Lack of knowledge about the system is one of the barriers in ERM execution and enhancement (Kleffner et al., 2003).

In the organizational context, culture is an important key factor that strengthens the business mission and defines the values that help in making decisions and making business strategies (Taneja et al., 2015). A strong organizational culture becomes a norm of behavior based on ethical values that creates a healthy work environment. Management must accept the need to manage its diverse workforce to get high-quality results that satisfy its consumers across the country. A firm's culture represents a common identical sense and stickiness among people that serves to mitigate any difference from a diverse cultural environment (Wahyuningsih et al., 2019). Adjustment of the organizational culture improves the efficiency of the company (Denison et al., 2004). It is expected that this will have a positive effect on the external adaptability and internal harmony that makes a corporation's efficiency possible. 
The organization receiving appropriate cultural support will benefit from positive employee attitudes, perception, ethical behavior, job satisfaction, and employee engagement. These benefits will surely enhance the organizational performance and long-term competitiveness of companies (Wahyuningsih et al., 2019).

This research has three benefits over the existing research. (1) The objective of this study is to examine empirically the argument that ERM is related to Competitive Advantage and how organizational culture moderates this relationship. (2) The research technique is more reasonable. ERM has not been appropriately addressed in Pakistan's academic and business environment. This holistic approach of risk management helps in minimizing the financial and management risks of a company. So, this study helps business leaders and risk managers working in the IT industry of Pakistan how to deal with uncertain circumstances. (3) The results are more in-depth. The organizational culture (organic) plays an important role in the implementation of ERM and helps an organization in getting a competitive advantage. In today's highly competitive environment, companies must act quickly to secure their financial position and market position. Businesses are continually striving to find ways to achieve sustainable competitive advantage. They must have more internal strengths to bring added value to the customer, strong differentiation, and scalability (Hamel, 1994).

\section{LITERATURE REVIEW}

\section{Theoretical Orientation for the Study}

Resource-Based View (RBV) theory and contingency theory are employed as the basic theoretical foundation that strongly supports the research model. RBV theory analyzes and interprets organizational internal resources and capabilities to formulate a strategy to attain sustainable competitive advantage. Resources can be measured as inputs for companies to operate. Internal resources and capabilities determine the strategic options of companies while competing in their external business environment. Business capabilities also permit companies to enhance the client's value chain, develop new products or enlarge into a new market. Thus, RBV leverages the resources and capabilities of the organization to develop sustainable competitive advantages. Whereas, Contingency approach consists of identifying the most common parameters and observing how different structures, strategies, and behavioral processes behave in each context (Hambrick, 1983). Richard Scott explains contingency theory as: "The best way to organize depends on the nature of the environment to which the organization must relate" (Scott, 1987, p. 89).

\section{Enterprise Risk Management}

ERM is an evaluation, quantification, financing, and risk management at the company level. It is a holistic approach for managing risk, so it can also create value for companies (Nocco \& Stulz, 2006). This paradigm concept highlights a broader view 
of risk and replaces the silo approach, which is compartmentalized from a department to another in an organization (Ching et al., 2020). ERM helps a firm in examining risks jointly and assessing the interaction of every risk with the firm's portfolio of other essential risks (Froot \& Stein, 1998). Thus, it improves the internal decision-making of an organization and leads toward more effective resource allocation and better capital structural decisions (Graham \& Rogers, 2002). Various models are presented "by a no. of researchers..." for ERM (Wu \& Olson, 2008). However, the most accepted model from prior scholars is the Committee of Sponsoring Organizations of the Treadway Commission (COSO, 2004) "ERM integrated framework" (Ahmad et al., 2014; Arena et al., 2010; Daud et al., 2010; Moeller, 2007; Olson \& Wu, 2015; Tahir \& Razali, 2011; Yazid et al., 2011).

The framework describes a risk management model in eight important components with four theme objectives. According to this framework, ERM components are "(1) internal environment: which is the basis for all other components. It includes many variables, such as entity's risk appetite; the entity's risk management philosophy; the entity's competence and ethical values development of personnel, and how the manager assigns responsibility and authority in organizations; (2) objective setting: It is a process to set objectives, which are consistent with the entity's risk appetite and its mission; (3) event identification: which means identification of both risks and opportunities that affect the achievement to entity's objectives from the internal and external environment; (4) risk assessment: it permits an entity to consider the impact and likelihood of events and analyzing risk by using both quantitative and qualitative approaches. It examines the positive and negative effects of potential events all over the entity; (5) risk response: management should select a proper reaction (avoiding, reducing, accepting, and sharing risk), which is in line with the risk tolerance and risk appetite of an entity; (6) control activities: it includes the policies and procedure which help a manager to ensure that risk responses are effectively performed at all level of organization; (7) information and communication: this means information communicate to staff in a form and timeframe, which helps them to fulfill their role and responsibility regarding ERM and other activities; and (8) monitoring: the ERM process and activities are monitored through separate evaluations, ongoing management activities, or both and modifications made as necessary (Saeidi et al., 2019). The framework proposes that a company's ERM mechanism should be positioned to attain the following four objectives: (1) strategy: high-level objectives, which are in line with the mission of the organization; (2) operations: short-level objectives, which are related to the efficient and effective use of the resources; (3) reporting: accuracy of the quality of organization's reporting system; and (4) compliance: acting according to accepted regulation and lows (Saeidi et al., 2019). Additionally, scholars must understand how the overall risk management 
process interacts with business attributes and other aspects of a company's strategy to influence its performance (Andersen, 2008, 2009).

\section{Relationship between ERM and Competitive Advantage}

Enterprise Risk management gets significant importance in recent years. Different organizations, agencies, public authorities, and stock exchanges have recognized the need to manage risks and have imposed several requirements to improve risk management practices in public companies. In the present work, there is a growing consensus among professionals and academics that ERM is the fundamental paradigm for managing the portfolio of risks faced by companies (Anton, 2018). An effective risk management practice can diminish the uncertainty variations in decision making, creates value for firms, and help in minimizing the undesirable impact on the company's performance both now and in the future (Faisal \& Hasan, 2020).

Effectively managing organizational risk will generate positive results. It acts as one of the key factors in gaining a competitive advantage. The first description is associated with the theory of RBV. The company's RBV has become a well-established theory of competitive advantage. The theory was first presented by Werner in 1984 (John, 2000). RBV stresses a firm's assets, internal organization competence, and recognition of resources to raise revenues and the strength of an organization (Nikmah et al., 2021). Many tangible and intangible resources are a part of an organization, resources that create value and scarce that helps in generating competitive advantage; and if resources are difficult to transfer, unique in nature, and imitable, they will provide benefits. These resources are called strategic assets (Barney, 1991). Given the above, ERM could be considered a strategic asset that generates a competitive advantage. Effectively managing your organizational risk could be examined as a primary foundation. Every organization has its systematic way of corresponding to its activities, mission, goals, and objectives (Beasley et al., 2005).

Consequently, the ERM system of one business cannot be applied to other different businesses. It is unique to everyone, and its success is precious to an organization, and no one can sell it (Hoyt \& Liebenberg, 2011). In addition, ERM creates advantages for organizations that use them, whereas other organizations cannot. Therefore, the theory of RBV explains that companies could gain a competitive advantage through the subsequent utilization of ERM as strategic assets. Finally, RBV theory states that organizations should use their resources optimally to obtain competitive advantages (Wade \& Hulland, 2004). As the capital and the fund resources are the crucial elements of the organization's resources. Their Ideal distribution in a secure environment is essential for the progress of a business. ERM permits firms and management to improve their capital distribution and investment opportunity effectively. As a result, they get a better position in the market (Beasley et al., 2005; COSO, 2004; Meier, 2000). 
Furthermore, if the company recognizes more about the risks of its sector than its competitors, it can properly manage these risks through taking active actions. Thus, they will handle opportunities and risks to organize a vision of both their disadvantages and their benefits (Nocco \& Stulz, 2006). Furthermore, by enhancing internal and external risk knowledge, they can adapt and change their situations quicker than competitors. Similarly, companies that integrate ERM into their business and strategic planning processes can make informed risk decisions (Meidell \& Kaarbøe, 2017). In that type of scenario, the chances of gaining monetary and non-monetary goals in organizations will be increased.

An appropriate risk management system can offer four kinds of benefits, which can lead to a competitive advantage. It leads to maintaining the organization serving its customers when they are notable, looking for more risky dealings, excellence in their daily performance, and establishing a strong image that helps in generating competitive advantage (Elahi, 2013).

H1: ERM has a positive impact on competitive advantage.

\section{ERM, Organizational Culture and Competitive Advantage}

Organizational culture is normally used for defining the internal environmental structure of an organization, as it is particularly important to make the organization more effective and has a long-term impact on the organization. The hallmark of a strong organizational identity is the existence of a strong organizational culture (Halmaghi et al., 2017).

The culture of an organization is strongly reflected in the congruence of vision, the existence of principles of command, teamwork, the creativity of employees, innovation, responsibility, harmonization of elements, the same direction and same objective, high coordination and integration, and the employee development according to the needs of the company. It is deeply embedded in the identity of the organization that cannot be easily changed. So, the impact of a strong organizational culture on the effectiveness of the organization can be positive or negative. The impact is positive when following organizational culture is a common practice among the members of an organization so that they accept it. It helps in achieving the objectives of the organization. The negative consequences happen when the organizational culture puts a negative impact on the goals of an organization (Halmaghi et al., 2017).

The culture of an organization is represented by its human resource management. Therefore, effectively managing your human capital will be a strong basis for gaining a competitive advantage. Conceptually, Susanto et al. (2008) defined organizational culture by the value for human resources to solve external problems, hurdles, and efforts to adopt integration into the organization. Hence, organizational members must adopt these values and should know how to behave and act. Organizations with excellent quality human resources should gain a competitive 
advantage because the excellent workforce improves the processes and results of the organization and, therefore, contributes to the success of the organization, as they make other resources in proper use (Pahuja, 2017).

Several competitive strategies, as well as human resources practices, have been studied that have a significant impact on employee performance. One study firmly confirmed that employees could gain a competitive advantage because they are the ones who do the business and can contribute to the success of the business. Human capital is the main asset of a company and should not be treated as an expense. Therefore, continuous efforts and learning should be made to create a healthy and knowledgeable environment with coaching, workshops, discussions, and regular advice to motivate learning and development (Choudhury \& Mishra, 2010).

ERM is known as a valuable initiative designed to help organizations perform better in ambiguity; it would not be irrational to expect the internal culture of an organization to be an important aspect in ERM deployment. In fact, ERM implementers encounter problems related to organizational culture. Numerous writings highlight the significance of organizational culture when implementing ERM programs. This study attempts to build a connection so that those who are responsible for the implementation of ERM can obtain useful information about the nature of the organizational culture with respect to ERM and what type of organizational culture is appropriately suitable for the implementation of an ERM system (Kimbrough \& Componation, 2009).
Different studies on ERM encourage the desirability of certain cultural attributes. It is necessary to move from the tradition of risk management within organizational silos to the management of portfolio risks by the entire entity (Leech, 2002). The organizational environment should support effective communication flow, collaboration among members, commitment, and employee engagement (Kimbrough \& Componation, 2009). Many explanations and frameworks describe ERM as a process that entails a mechanistic set of attributes like centralization, proper obedience to the supervisor, and a long chain of command. It advocates adherence to rigorous activities that include "systematic identification, examining, prioritization, monitoring, control activities and practice of a common risk language" (Kimbrough \& Componation, 2009).

Leech (2002) describes the traditional approach and the new modernistic vision for risk control and governance. The first comprises the role of management in the assignment of tasks and supervision of personnel, the environment governed by policies and rules, and limited employee participation. The new vision has a culture of continuous improvement and encourages the participation of members in the organization (Leech, 2000). Lam (2014) explains that there are two sides to managing risk. The hard side consists of risk policies, procedures, and audit processes, whereas the soft side includes risk awareness, individuals, trust, and communication. Lam (2014) advocates a balance among the soft and hard sides (Lam, 2014). Leech 
(2002) strongly supports the new vision because organic culture is more likely to adopt change and effectively manage your risk in the organization (Kimbrough \& Componation, 2009).

For ERM implementation, an organic culture must be created that supports innovative ideas, strategic leadership, competitiveness, and a strategic focus on customers. Organizations dominated by the attributes of organic design are considered to generate and move knowledge within the organization more effectively and respond quickly to challenges that pressurize and affect organizational performance (Stojanović-Aleksić et al., 2019). In addition, to improve competitiveness, ERM must need to filter and monitor internal as well as external. It requires the collection of data and information, and then its analysis, identifying events both in terms of opportunities and threats, proper analysis of those events, then picking the best response for controlling them (COSO, 2004).

From another point of view, based on the theory of contingency, organizations are composed of a hundred and thousands of inter-related subsystems. Therefore, they cannot be seen in a one-dimensional aspect (Reinking, 2012). Contingency theory explains that "there is no valid bivariate relationship between two variables and the effect of the independent variable on dependent variable depends upon some third variable (interaction, moderator or mediator). It means that the relationship between two variables is part of a large causal system involving other variables so that the valid generalization takes the form of trivariate or more relationships" (Saeidi et al., 2019). A relationship of two variables is too easy for capturing the law as the regularity connection. Hence, the more complex statement is essential (Donaldson, 2006).

This research delivers a detailed view on the applications of organizational culture and ERM in organizations. The research model with hypothesis is presented in Figure 1.

H2: Organizational culture has a positive moderation impact on ERM and competitive advantage relationship.

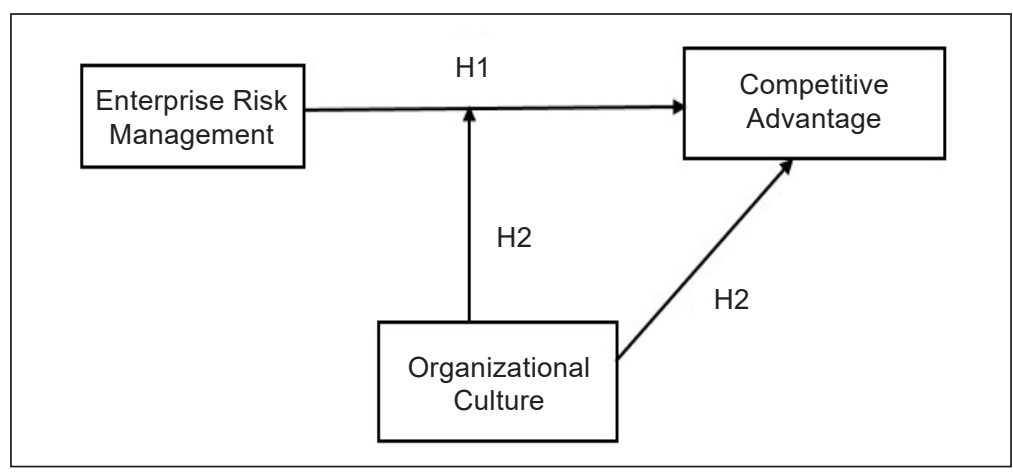

Figure 1. Research model and hypotheses 


\section{DATA AND METHODOLOGY}

This study was anchored on positivism philosophy because it complies with only factual knowledge gained through observations, including measurement. This type of philosophy depends on quantifiable observations that lead to statistical analyses. A crosssectional research design has been used to understand the linkages between the variables. The population selected for the research study is the software houses of Islamabad and Rawalpindi, Pakistan that was 1,114 in number. In Islamabad, there are 245 software houses, which are registered, while in Rawalpindi, only 80 Software Houses are registered in PSEB Registered Companies of 2019. So, there are 325 registered software houses in Islamabad and Rawalpindi. The average working employees in a Software House are 8-9 employees and above (Sekaran \& Bougie, 2019). This study conducted a questionnaire survey as a research method. Data is collected from all experienced managers and employees practicing the ERM system in their organizations and managed to give time to my survey. A total of 300 selfadministered questionnaires were distributed among the respondents. Two hundred seventy-five were returned. The response of 25 employees was irrelevant as they had not filled the questionnaire, and many of the statements were unfilled. Therefore, the response of only 250 employees was considered for the analysis, and this makes the response rate $83.33 \%$. Data analysis was done through SPSS and PLS-SEM, such as mean, standard deviation, correlation, and hypothesis testing.

\section{Variable Measurement}

Twenty-three items were used for measuring all eight components of ERM. Seven Items were related to the firm's competitive advantage. The scale was adopted from (Saeidi et al., 2019). In addition, the eight items were used for organizational culture (adapted from (Wahyuningsih et al., 2019). All questions were measured on a 5-point Likert scale varying from $1=$ strongly disagree to $5=$ strongly agree). The details are documented in Table 1.

For the dependent variable CA, the mean Is 2.2023, and the standard deviation is 1.02212. The highest mean value of ERM, i.e., 2.6246 with a corresponding standard deviation of 0.71606 . The correlation analysis is given in Table 2. The results indicate a high positive correlation between

Table 1

Descriptive statistics

\begin{tabular}{lccc}
\hline & Number of Observations & Mean & SD \\
\hline ERM & 250 & 2.6246 & 0.71606 \\
OC & 250 & 2.5053 & 0.78698 \\
CA & 250 & 2.2023 & 1.02212 \\
Valid N (listwise) & 250 & & \\
\hline
\end{tabular}

Note: $\mathrm{ERM}=$ Enterprise Risk Management, $\mathrm{OC}=$ Organizational Culture, $\mathrm{CA}=$ Competitive Advantage 
ERM and $\mathrm{OC}(\mathrm{r}=.774, \mathrm{p}<.01)$. ERM and $\mathrm{CA}$ are positively correlated $(\mathrm{r}=.732, \mathrm{p}<.01)$. $\mathrm{OC}$ and $\mathrm{CA}$ are also positively correlated $(\mathrm{r}=.884, \mathrm{p}<.01)$. Therefore, it can be interpreted that ERM and Competitive Advantage have a positive impact on Organizational Culture.

To check the multi-collinearity, we examined tolerance and the Variance Inflation Factor (VIF). Tolerance and VIF have been measured by using SPSS. VIF value must be less than five, and the tolerance is greater than 0.2 , then it can be concluded that there is no problem of multi-collinearity (Hair Jr et al., 2014). In Table 3, it is clear from the collinearity statistics that the VIF value for ERM and Organizational Culture is 2.491. All values are below threshold 5 . The tolerance is the opposite of VIF and should be greater than 0.2. All tolerance values are above the threshold of 0.20 , which is 0.401 for ERM and 0.401 for Organizational Culture. Hence the conclusion of the analysis is that there is no multi-collinearity problem in the data.

\section{EMPIRICAL FINDINGS}

Structural Equation Modeling (SEM) and Partial Least Square (PLS) were conducted to test the hypothesis. PLS is an SEM technique that maximizes the explained variance (rather than covariance) of endogenous constructs (Hair Jr et al., 2021). SEM is a multivariate analysis technique that is used to study the structural connections. SEM contains factor analysis and multiple regression analysis, and it is utilized to examine the relationships

Table 2

Correlations among variables

\begin{tabular}{llccc}
\hline & & ERM & OC & CA \\
\hline ERM & Pearson Correlation & 1 & $.774^{* *}$ & $.732^{* *}$ \\
& Sig. (2-tailed) & & .000 & .000 \\
& N & 250 & 250 & 250 \\
OC & Pearson Correlation & $.774^{* *}$ & 1 & $.884^{* *}$ \\
& Sig. (2-tailed) & .000 & & .000 \\
& N & 250 & 250 & 250 \\
\multirow{2}{*}{ CA } & Pearson Correlation & $.732^{* *}$ & $.884^{* *}$ & 1 \\
& Sig. (2-tailed) & .000 & .000 & 250 \\
\hline
\end{tabular}

Note: ** Correlation is significant at the 0.01 level (2-tailed)

Table 3

Results of multicollinearity

\begin{tabular}{llcc}
\hline \multirow{2}{*}{ S.No. } & Variables & \multicolumn{2}{c}{ Collinearity Statistics } \\
\cline { 3 - 4 } & & VIF & Tolerance \\
\hline 1 & ERM & 2.491 & 0.401 \\
2 & Organizational Culture & 2.491 & 0.401 \\
\hline
\end{tabular}


among the latent and measured constructs Structural Equation Modeling (SEM). Path models are made up of two elements: (1) the "structural model," which designates the associations among the latent variables, and (2) the "measurement model," which pronounces the relations between the latent variables and their measures (i.e., their indicators). The empirical findings were analyzed in two steps. First, the validity and reliability of the scales "measurement model" were scrutinized, and second, the "structural model (hypotheses testing)" was verified.

\section{Measurement Model}

In order to assess the measurement model, CFA was conducted, and results are shown in Table 4. Cronbach alpha, CR estimates, and Average Variance Extracted were higher than the cut-off values of .7 and .5 , respectively. Benchmark for factor loadings is .7. The analysis shows that all the values were higher than the standard range. Therefore, two items were removed from the variable organizational culture and nine from ERM due to the lower factor loading (Hair Jr et al., 2014).

Table 4

AVE and reliability of the variables

\begin{tabular}{|c|c|c|c|c|c|}
\hline Constructs & Items & Loadings & Cronbach Alpha & $\mathbf{C R}$ & AVE \\
\hline $\begin{array}{l}\text { Enterprise Risk } \\
\text { Management }\end{array}$ & $\begin{array}{c}\text { CA1 } \\
\text { CA2 } \\
\text { CA3 } \\
\text { EI1 } \\
\text { IC1 } \\
\text { IC2 } \\
\text { IE1 } \\
\text { M1 } \\
\text { M2 } \\
\text { M3 } \\
\text { RA1 } \\
\text { RA2 } \\
\text { RR1 } \\
\text { RR2 }\end{array}$ & $\begin{array}{l}0.818 \\
0.761 \\
0.797 \\
0.786 \\
0.764 \\
0.773 \\
0.689 \\
0.724 \\
0.809 \\
0.824 \\
0.853 \\
0.732 \\
0.714 \\
0.678\end{array}$ & 0.946 & 0.952 & 0.589 \\
\hline $\begin{array}{l}\text { Organizational } \\
\text { Culture }\end{array}$ & $\begin{array}{l}\text { OC1 } \\
\text { OC2 } \\
\text { OC4 } \\
\text { OC5 } \\
\text { OC7 } \\
\text { OC8 }\end{array}$ & $\begin{array}{l}0.815 \\
0.814 \\
0.786 \\
0.791 \\
0.869 \\
0.884 \\
\end{array}$ & 0.907 & 0.929 & 0.685 \\
\hline $\begin{array}{l}\text { Competitive } \\
\text { Advantage }\end{array}$ & $\begin{array}{l}\mathrm{C} 1 \\
\mathrm{C} 2 \\
\mathrm{C} 3 \\
\mathrm{C} 4 \\
\mathrm{C} 5 \\
\mathrm{C} 6 \\
\mathrm{C} 7\end{array}$ & $\begin{array}{l}0.853 \\
0.900 \\
0.855 \\
0.807 \\
0.885 \\
0.903 \\
0.872\end{array}$ & 0.945 & 0.955 & 0.754 \\
\hline
\end{tabular}


Cronbach alpha was calculated for Organizational Culture after construct authentication was calculated and was .907, and composite reliability was .929 , which designates a high correlation amongst the objects, and the scale is consistent.

Discriminant validity was conducted by (Fornell \& Larcker, 1981) test at the construct level and Cross-loading at the item level. Overall, the measurement model is accepted and supports the discriminant validity among the constructs shown in Table 5.

Table 5

Fornell and Larcker's test

\begin{tabular}{lccc}
\hline Variables & CA & ERM & OC \\
\hline CA & 0.868 & & \\
ERM & 0.742 & 0.767 & \\
OC & 0.807 & 0.672 & 0.827 \\
\hline
\end{tabular}

\section{Structural Model (Hypothesis Testing)}

Figure 2 shows the beta values and factor loadings. The beta value for the proposed relationship is .197, which shows that the connection between ERM and Competitive Advantage is positive, and the impact of ERM on Competitive Advantage is $19.7 \%$. The beta value for the proposed relationship is 0.418 , which shows that the relationship between organizational culture and competitive advantage is positive, and the impact of organizational culture and competitive advantage is $41.8 \%$. Therefore, the Organizational Culture has moderates by .357 and buffers the relationship by $35.7 \%$ between ERM and Competitive Advantage. $T$ values of all the variables are accepted and are within the standard range (Figure 3). According to Hair Jr et al. (2021), the acceptable values range from 1.96 and above as the $T$ value range is greater than 1.96 and the $P$ value less than $.05 . T=7.142$ for moderating effect, and the same goes for the $\mathrm{p}$-value, i.e., $\mathrm{p}=.000$, which is lower than .05 . In this respect, the above analysis shows that relationships, which have

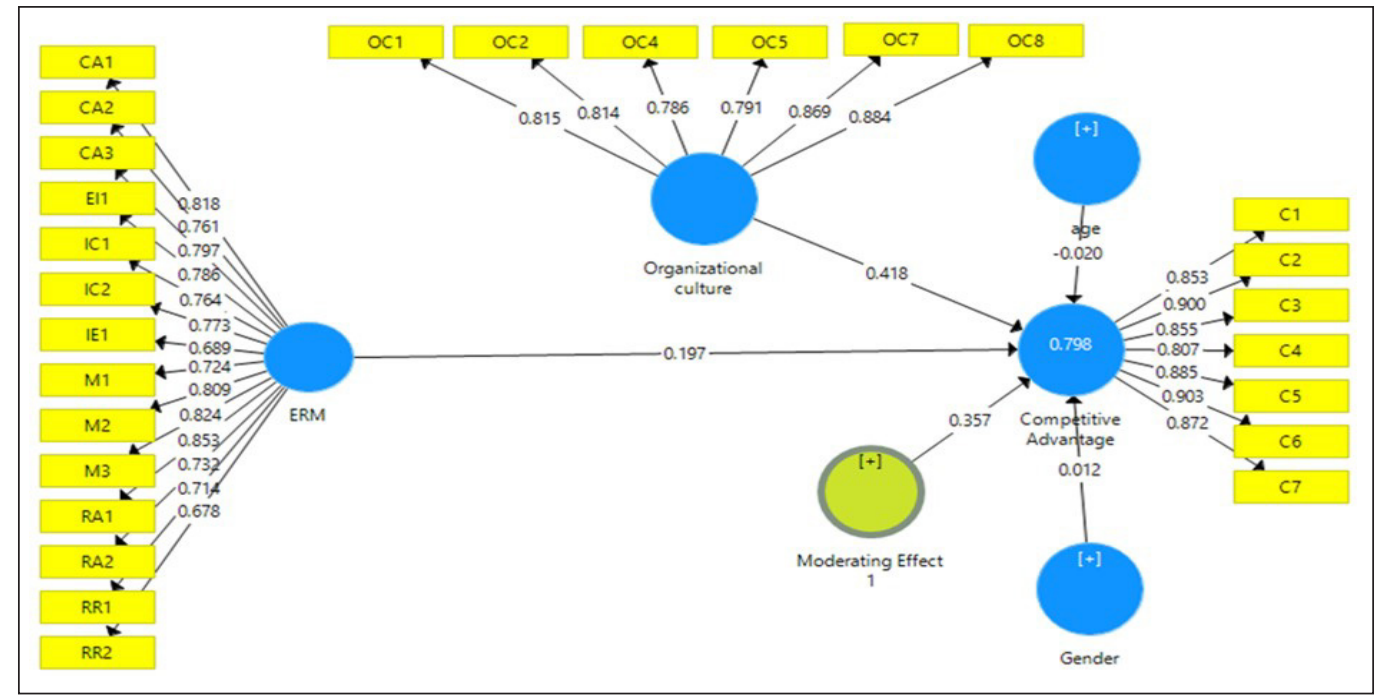

Figure 2. Beta values and factor loadings 


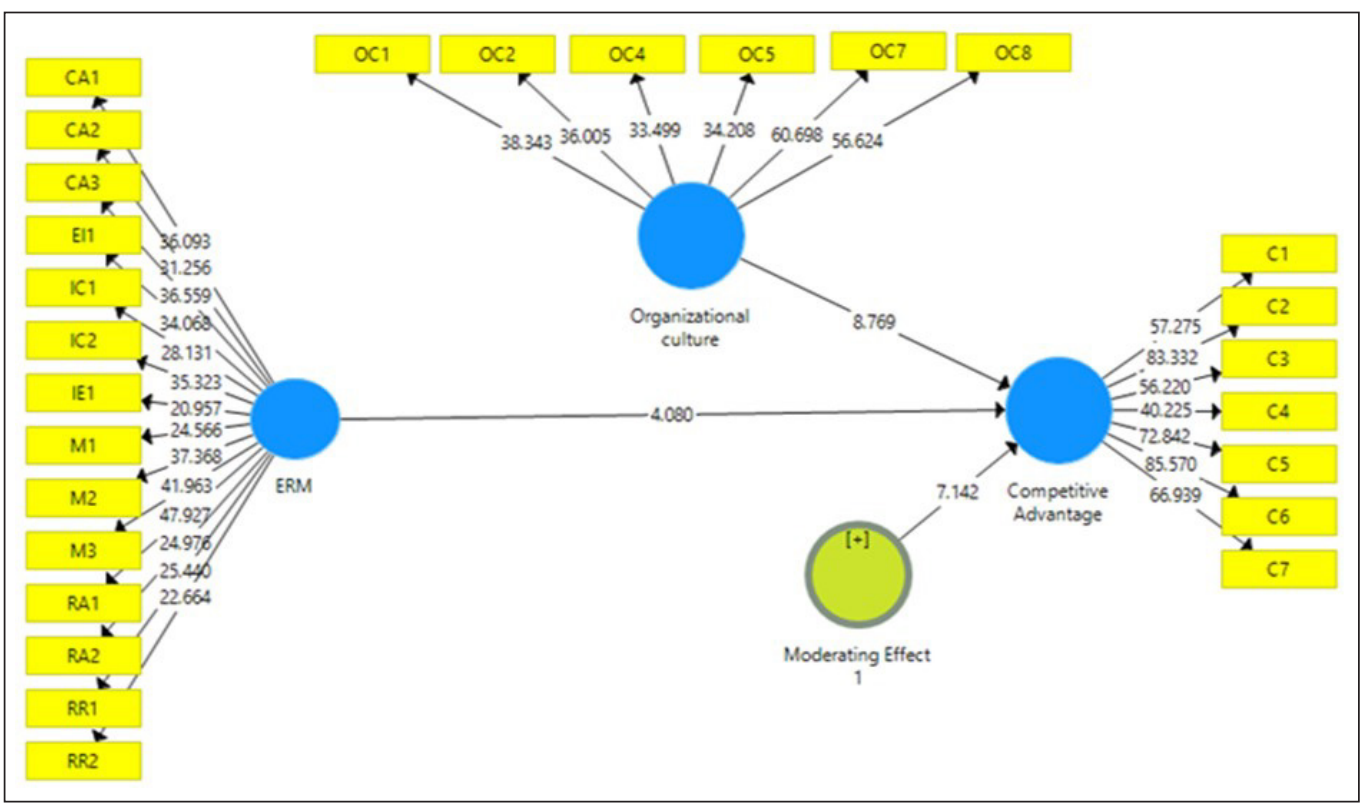

Figure 3. Significance results (T-values)

standard values are significant. Hence, H2 is accepted.

Substantive factor model values must be significant rather than method factor loadings. Table 6 shows that there is no issue of common method bias. In PLS, the UMLC approach was used to measure the common method variance (Marcoulides \& Chin, 2013).

\section{CONCLUSION AND RECOMMENDATIONS}

This study aimed to model enterprise risk management and competitive advantage moderated by organizational culture. As stated in the literature part that ERM could affect almost every part of an organization. Empirical evidence on the relationship between ERM and competitive advantage is still limited. Our study utilizes SEM for examining the connections among the constructs (ERM, OC, and CA). Therefore, this study contributes such links empirically by considering all software houses of Islamabad and Rawalpindi, Pakistan, using the ERM program. This research explores that ERM showed a significant influence upon organizational competitive advantage (Saeidi et al., 2019). ERM helps in improving work performance and increases profit, shareholder value, and is considered as a strategic tool for an organization's success (Annamalah et al., 2018). It is extremely important for the companies to identify and acknowledge their risks and be more aware to detect any danger, especially more so that they can compete with their rivals. With this information in hand, a company can fit in a rapidly changing environment (Saeidi et al., 2019). Organizational culture shapes desirable organizational behavior and practices, and our results showed 
Table 6

Common Method Variance (CMV)

\begin{tabular}{|c|c|c|c|c|c|}
\hline Constructs & Indicators & $\begin{array}{c}\text { Substantive } \\
\text { Factor Loadings } \\
\text { (R1) }\end{array}$ & $\mathbf{R} \mathbf{1}^{2}$ & $\begin{array}{l}\text { Method } \\
\text { Factor } \\
\text { Loading } \\
\text { (R2) }\end{array}$ & $\mathbf{R} 2^{2}$ \\
\hline \multirow{14}{*}{$\begin{array}{l}\text { Enterprise Risk } \\
\text { Management }\end{array}$} & CA1 & 0.768 & 0.589 & -0.075 & 0.00562 \\
\hline & $\mathrm{CA} 2$ & 1.005 & 1.010 & -0.231 & 0.053 \\
\hline & CA3 & 1.214 & 1.473 & -0.380 & 0.144 \\
\hline & EI1 & 0.763 & 0.582 & -0.032 & 0.001 \\
\hline & $\mathrm{IC} 1$ & 0.487 & 0.237 & 0.230 & 0.052 \\
\hline & IC2 & 0.704 & 0.495 & -0.017 & 0.00028 \\
\hline & IE1 & 0.758 & 0.574 & 0.061 & 0.0037 \\
\hline & M1 & 0.689 & 0.474 & 0.068 & 0.0046 \\
\hline & M2 & 0.643 & 0.413 & 0.161 & 0.025 \\
\hline & M3 & 0.797 & 0.635 & -0.026 & 0.00067 \\
\hline & RA1 & 0.489 & 0.239 & 0.290 & 0.084 \\
\hline & RA2 & 0.822 & 0.675 & -0.095 & 0.009025 \\
\hline & RR1 & 0.905 & 0.819 & -0.098 & 0.009604 \\
\hline & RR2 & 0.647 & 0.418 & 0.180 & 0.0324 \\
\hline \multirow[t]{6}{*}{ Organizational Culture } & $\mathrm{OC} 1$ & 0.851 & 0.724 & -0.039 & 0.001521 \\
\hline & $\mathrm{OC} 2$ & 0.933 & 0.870 & -0.126 & 0.0158 \\
\hline & $\mathrm{OC} 4$ & 0.870 & 0.756 & -0.099 & 0.0098 \\
\hline & OC5 & 0.377 & 0.142 & 0.463 & 0.214 \\
\hline & OC7 & 0.879 & 0.772 & -0.013 & 0.000169 \\
\hline & OC8 & 1.030 & 1.060 & -0.162 & 0.026 \\
\hline \multirow[t]{7}{*}{ Competetive Advantage } & $\mathrm{C} 1$ & 0.947 & 0.896 & -0.101 & 0.010 \\
\hline & $\mathrm{C} 2$ & 0.815 & 0.664 & 0.090 & 0.0081 \\
\hline & $\mathrm{C} 3$ & 1.230 & 1.512 & -0.407 & 0.165 \\
\hline & $\mathrm{C} 4$ & 1.003 & 1.006 & -0.213 & 0.045 \\
\hline & $\mathrm{C} 5$ & 0.625 & 0.390 & 0.281 & 0.078 \\
\hline & C6 & 0.829 & 0.687 & 0.080 & 0.0064 \\
\hline & $\mathrm{C} 7$ & 0.661 & 0.436 & 0.229 & 0.052 \\
\hline
\end{tabular}

that organic organizational culture (i.e., innovation and outcome orientation) affects the use of ERM practices in a positive manner (Chen et al., 2019). First, we established and tested the existence of the relationships (hypotheses) between the constructs. Second, we investigated the impact of organizational culture on ERM and CA. Finally, the model was tested. The results indicated that this positive and significant effect of ERM on CA would increase as the organizational culture level increases (Saeidi et al., 2019).

The results of this study extend our knowledge in numerous ways. First, the present work on enterprise risk management 
is among few studies that consider this holistic approach of managing risk in a country like Pakistan. Although, previous studies have focused on the relationship between enterprise risk management and competitive advantage as an important aspect of resolving organizational risk, increasing a company's profit, etc. Second, the model of the study focused on the moderating role of organizational culture on the association between ERM and competitive advantage. Thus, as per scholars' knowledge, this study is among the first to highlight organizational culture as the prominent aspect, which can positively increase the effect of ERM on firm competitive advantage.

In the perspective of practical contribution, first, this study helps management and employees of the software industry to manage their risk more effectively as compared to the traditional risk management system. Second, the software industry of Pakistan is growing very rapidly, and the competition among them is also very aggressive. In this state, ERM and organic organizational culture help in improving organizational performance. Hence, developing competency of improving risk management system motivates organizations and managers to grow and earn profit. Further, organizations get better global and local market position and give good competition to their competitors.

The current research findings establish a clear understanding of control systems and risk management. Organic cultures would lead to superior ERM implementation that further increases organizational competitiveness. The correlation simplifies the result that organizational culture (organic) is more likely to deal with change, whether in the form of a new ERM program or any other significant shift in management or technology (Kimbrough \& Componation, 2009). The present research indicates a positive correlation among all variables. It illustrates that the ERM has a positive impact on CA with a standardized regression weight of .197. In contrast, OC has a significant effect on CA with a standardized regression weight of .418 . The OC significantly and positively moderates the effect of ERM on CA with a standardized regression weight of .357 . This research study will provide the insightful inclination to the employees, managers, and top executives of the organizations to act responsibly in a rapidly changing environment and help in accomplishing organizational competitiveness.

This study has enhanced our understanding of managing organizational risk and highlights the significance of designing a sophisticated ERM system to deal with unfavorable circumstances. However, as it helps in consolidating our understanding in the area, it has several limitations that can be introduced as some interesting future research projects. First, this study incorporated a "cross-sectional analysis plan," which allows the researcher to gather data at one point in time, but "longitudinal research" approaches can also be considered to examine their relations and whether the relations change over time. Second, the researcher could expand the 
model or introduce other organizational factors as moderators or mediators (e.g., organizational performance, training, innovation, employee engagement). Third, the study focused on software houses working in Islamabad and Rawalpindi, Pakistan. In the future, the study could be replicated with other software houses working in different cities having different organizational settings to check whether the study's findings apply to a broad range of environments in Pakistan. Lastly, the current study conducted a questionnaire survey, while in the future, it should be done by evaluating the casual interactions of variables through interviews or observations method and might be a better vision for the findings of this study.

\section{ACKNOWLEDGEMENT}

We thank Dr. Fahad Amjad for proofreading and editorial corrections.

\section{REFERENCES}

Ahmad, S., Ng, C., \& McManus, L. A. (2014). Enterprise risk management (ERM) implementation: Some empirical evidence from large Australian companies. Procedia-Social and Behavioral Sciences, 164, 541-547. https://doi. org/10.1016/j.sbspro.2014.11.144

Andersen, T. J. (2008). The performance relationship of effective risk management: Exploring the firm-specific investment rationale. Long Range Planning, 41(2), 155-176. https://doi. org/10.1016/j.lrp.2008.01.002

Andersen, T. J. (2009). Effective risk management outcomes: Exploring effects of innovation and capital structure. Journal of Strategy and Management, 2(4), 352-379. https://doi. org/10.1057/9781137447623_5

Annamalah, S., Raman, M., Marthandan, G., \& Logeswaran, A. K. (2018). Implementation of Enterprise Risk Management (ERM) framework in enhancing business performances in oil and gas sector. Economies, 6(1), 4. https://doi. org/10.3390/economies6010004

Anton, S. G. (2018). The impact of enterprise risk management on firm value: Empirical evidence from Romanian non-financial firms. Engineering Economics, 29(2), 151-157. https:// doi.org/10.5755/j01.ee.29.2.16426

Arena, M., Arnaboldi, M., \& Azzone, G. (2010). The organizational dynamics of enterprise risk management. Accounting, Organizations and Society, 35(7), 659-675. https://doi. org/10.1016/j.aos.2010.07.003

Barney, J. (1991). Firm resources and sustained competitive advantage. Journal of Management, 17(1), 99-120. https://doi. org/10.1177/014920639101700108

Beasley, M. S., Clune, R., \& Hermanson, D. R. (2005). Enterprise risk management: An empirical analysis of factors associated with the extent of implementation. Journal of Accounting and Public Policy, 24(6), 521-531. https://doi. org/10.1016/j.jaccpubpol.2009.06.006

Berry-Stölzle, T. R., \& Xu, J. (2018). Enterprise risk management and the cost of capital. Journal of Risk and Insurance, 85(1), 159-201. https://doi. org/10.1111/jori.12152

Chen, J., Jiao, L., \& Harrison, G. (2019). Organisational culture and enterprise risk management: The Australian not-for-profit context. Australian Journal of Public Administration, 78(3), 432448. https://doi.org/10.1111/1467-8500.12382

Chen, Y.-L., Chuang, Y.-W., Huang, H.-G., \& Shih, J.Y. (2020). The value of implementing enterprise risk management: Evidence from Taiwan's 
financial industry. The North American Journal of Economics and Finance, 54, 100926. https:// doi.org/10.1016/j.najef.2019.02.004

Ching, W. C., Mohd-Rahim, F., Chuing, L. S., Zainon, N., \& Aziz, N. (2020). Conceptualising risk culture on Enterprise Risk Management (ERM) implementation in construction companies. Built Environment, 17(1), 58-69. https://doi. org/10.24191/bej.v17i1.5988

Choudhury, J., \& Mishra, B. (2010). Theoretical and empirical investigation of impact of developmental HR configuration on human capital management. International Business Research,3(4), 181-186. https://doi.org/10.5539/ ibr.v3n4p181

Committee of Sponsoring Organizations of the Treadway Commission. (2004). Enterprise risk management-Integrated framework. COSO

Daud, W. N. W. D., Yazid, A. S., \& Hussin, M. R. (2010). The effect of chief risk officer (CRO) on enterprise risk management (ERM) practices: Evidence from Malaysia. International Business \& Economics Research Journal, 9(11), 55-64. https://doi.org/10.19030/iber.v9i11.30

Denison, D. R., Haaland, S., \& Goelzer, P. (2004). Corporate culture and organizational effectiveness: Is Asia different from the rest of the world? Organizational Dynamics, 33(1), 98-109. https://doi.org/10.1016/j.orgdyn.2003.11.008

Donaldson, L. (2006). The contingency theory of organizational design: Challenges and opportunities. In Organization design (pp. 1940). Springer.

Elahi, E. (2013). Risk management: the next source of competitive advantage. Foresight-The Journal of Future Studies, Strategic Thinking and Policy, 15(2), 117-131. https://doi. org/10.1108/14636681311321121

Faisal, M., \& Hasan, N. N. (2020). Enterprise Risk Management and firm value: The case in emerging market. International Journal of Innovation, Creativity and Change, 11(6), 272-286.

Fornell, C., \& Larcker, D. F. (1981). Evaluating structural equation models with unobservable variables and measurement error. Journal of Marketing Research, 18(1), 39-50. https://doi. org/10.1177\%2F002224378101800104

Froot, K. A., \& Stein, J. C. (1998). Risk management, capital budgeting, and capital structure policy for financial institutions: an integrated approach. Journal of Financial Economics, 47(1), 55-82. https://doi.org/10.1016/S0304-405X(97)00037-8

Gatzert, N., \& Martin, M. (2015). Determinants and value of enterprise risk management: Empirical evidence from the literature. Risk Management and Insurance Review, 18(1), 29-53.

Graham, J. R., \& Rogers, D. A. (2002). Do firms hedge in response to tax incentives? The Journal of Finance, 57(2), 815-839. https://doi. org/10.1111/1540-6261.00443

Grant, R. M. (1996). Toward a knowledge-based theory of the firm. Strategic Management Journal, 17(S2), 109-122. https://doi.org/10.1002/ smj.4250171110

Hair Jr, J. F., Hult, G. T. M., Ringle, C. M., \& Sarstedt, M. (2021). A primer on Partial Least Squares Structural Equation Modeling (PLS-SEM). Sage publications.

Hair Jr, J. F., Sarstedt, M., Hopkins, L., \& Kuppelwieser, V. G. (2014). Partial Least Squares Structural Equation Modeling (PLSSEM): An emerging tool in business research. European Business Review, 26(2), 106-121. https://doi.org/10.1108/EBR-10-2013-0128

Halmaghi, E. E., Iancu, D., \& Băcilă, M. L. (2017). The organization's internal environment and its importance in the organization's development. International Conference Knowledge-Based Organization, 23(1), 378-381. 
Hambrick, D. C. (1983). An empirical typology of mature industrial-product environments. Academy of Management Journal, 26(2), 213230. https://doi.org/10.5465/255971

Hamel, G. (1994). The concept of core competence. Competence-Based Competition, 5(1), 11-33.

Hoyt, R. E., \& Liebenberg, A. P. (2011). The value of enterprise risk management. Journal of Risk and Insurance, 78(4), 795-822. https://doi. org/10.1111/j.1539-6975.2011.01413.x

Jabbour, M., \& Abdel-Kader, M. (2015). Changes in capital allocation practices-ERM and organisational change. Accounting Forum, 39(4), 295-311. https://doi.org/10.1016/j. accfor.2015.08.001

John, F. (2000). The resource-based view of the firm: Some stumbling-blocks on the road to understanding sustainable competitive advantage. Journal of European Industrial Training, 24(2-4), 94-104. https://doi. org/10.1108/03090590010321061

Kimbrough, R. L., \& Componation, P. J. (2009). The relationship between organizational culture and enterprise risk management. Engineering Management Journal, 21(2), 18-26. https://doi. org/10.1080/10429247.2009.11431803

Kleffner, A. E., Lee, R. B., \& McGannon, B. (2003). The effect of corporate governance on the use of enterprise risk management: Evidence from Canada. Risk Management and Insurance Review, 6(1), 53-73. https://doi. org/10.1111/1098-1616.00020

Lam, J. (2014). Enterprise risk management: From incentives to controls. John Wiley \& Sons.

Leech, T. J. (2000). The next wave in assurance thinking. Internal Auditor, 57(4), 66-71.

Leech, T. J. (2002). Regulatory revolution risks civil war. Algo Research Quarterly, 5(2), 1-11.

Marcoulides, G. A., \& Chin, W. W. (2013). You write, but others read: Common methodological misunderstandings in PLS and related methods. In New perspectives in partial least squares and related methods (pp. 31-64). Springer.

Meidell, A., \& Kaarbøe, K. (2017). How the enterprise risk management function influences decisionmaking in the organization-A field study of a large, global oil and gas company. The British Accounting Review, 49(1), 39-55. https://doi. org/10.1016/j.bar.2016.10.005

Meier, R. L. (2000). Integrating enterprise-wide risk management concepts into industrial technology curricula. Journal of Industrial Technology, 16(4), 1-15.

Moeller, R. R. (2007). COSO enterprise risk management: Understanding the new integrated ERM framework. John Wiley \& Sons.

Nikmah, F., Rahmawati, R., \& Sukma, E. A. (2021). Resource-based view: Implementation in Indonesia SMEs to achieve competitive advantage. European Journal of Research and Reflection in Management Sciences, 9(1), 13-22.

Nocco, B. W., \& Stulz, R. M. (2006). Enterprise risk management: Theory and practice. Journal of Applied Corporate Finance, 18(4), 8-20. https:// doi.org/10.1111/j.1745-6622.2006.00106.x

Nonaka, I., Kodama, M., Hirose, A., \& Kohlbacher, F. (2014). Dynamic fractal organizations for promoting knowledge-based transformation-A new paradigm for organizational theory. European Management Journal, 32(1), 137146. https://doi.org/10.1016/j.emj.2013.02.003

Olson, D. L., \& Wu, D. D. (2015). Enterprise Risk Management in finance. Springer.

Pahuja, S. (2017). Impact of human resource system on competitive advantage status: A case study. Pacific Business Review International, 9(11), 112-118.

Reinking, J. (2012). Contingency theory in information systems research. In Information Systems Theory (pp. 247-263). Springer. 
Saeidi, P., Saeidi, S. P., Sofian, S., Saeidi, S. P., Nilashi, M., \& Mardani, A. (2019). The impact of enterprise risk management on competitive advantage by moderating role of information technology. Computer Standards \& Interfaces, 63, 67-82. https://doi.org/10.1016/j. csi.2018.11.009

Scott, W. R. (1987). Organizations: Rational, natural, and open systems. Prentice hall.

Sekaran, U., \& Bougie, R. (2019). Research methods for business: A skill building approach. John Wiley \& Sons.

Simons, R. (1990). The role of management control systems in creating competitive advantage: new perspectives. Accounting, Organizations and Society, 15(1-2), 127-143. https://doi. org/10.1016/0361-3682(90)90018-P

Stojanović-Aleksić, V., Erić Nielsen, J., \& Bošković, A. (2019). Organizational prerequisites for knowledge creation and sharing: empirical evidence from Serbia. Journal of Knowledge Management, 23(8), 1543-1565. https://doi. org/10.1108/JKM-05-2018-0286

Susanto, A., Sujanto, F., Wijanarko, H., Susanto, P., Mertosono, S., \& Ismangil, W. (2008). Corporate Culture \& Organization Culture. Jakarta: The Jakarta Consulting Group.

Tahir, I. M., \& Razali, A. R. (2011). The Relationship between enterprise risk management (ERM) and firm value: Evidence from Malaysian public listed companies. International Journal of Economics and Management Sciences, 1(2), 32-41. https://doi.org/10.1016/03613682(90)90018-P
Taneja, S., Sewell, S. S., \& Odom, R. Y. (2015). A culture of employee engagement: A strategic perspective for global managers. Journal of Business Strategy, 36(3), 46-56. https://doi. org/10.1108/JBS-06-2014-0062

Tekathen, M., \& Dechow, N. (2013). Enterprise risk management and continuous re-alignment in the pursuit of accountability: A German case. Management Accounting Research, 24(2), 100121. https://doi.org/10.1016/j.mar.2013.04.005

Wade, M., \& Hulland, J. (2004). The resource-based view and information systems research: Review, extension, and suggestions for future research. MIS Quarterly, 28(1), 107-142. https://doi. org $/ 10.2307 / 25148626$

Wahyuningsih, S. H., Sudiro, A., Troena, E. A., \& Irawanto, D. (2019). Analysis of organizational culture with Denison's model approach for international business competitiveness. Problems and Perspectives in Management, 17(1), 142-151. http://dx.doi.org/10.21511/ ppm.17(1).2019.13

Wu, D., \& Olson, D. (2008). Enterprise risk management: Financial and accounting perspectives. In New frontiers in enterprise risk management (pp. 25-38). Springer. https://doi. org/10.1007/978-3-540-78642-9_3

Yazid, A. S., Hussin, M. R., \& Daud, W. N. W. (2011). An examination of Enterprise Risk Management (ERM) practices among the government-linked companies (GLCs) in Malaysia. International Business Research, 4(4), 94-103. 10.5539/ibr. v4n4p94 
